\title{
Lobbying for a faster integration track for the western Balkans region
}

\begin{abstract}
The European Union's actions in the western Balkans region is guided by the principles which have inspired its own creation, development and enlargement. Nevertheless, the countries of the region area are still impatiently waiting for a confirmation of the Thessaloniki Agenda conclusions in the new Enlargement Strategy for 2010/2011, which will have a strong impact on the region's further integration dynamic. There is a unique stance among all the countries of the region that it is necessary to lobby for a faster integration track, requiring all potential candidate countries promptly to understand the manners and rules of functioning of the complex EU system. In that sense, western Balkan countries have, to different extents, developed lobbying networks. Each country needs to create the institutional set up for lobbying, registers of professional lobbyists and codes of conduct for lobbyists, with a full understanding of the relevant machinery of decision-making, which will help them to influence the process concerning the enlargement dynamic.
\end{abstract}

Keywords: European Union, enlargement, criteria, EU accession negotiations, western Balkans, Montenegro, lobbying.

\section{Introduction}

The EU, as mentioned in the Treaty on the European Union, is based on the values of respect for human dignity, freedom, democracy, equality and the rule of law, as well as on respect for human rights, including people that belong to national minorities.

The association process to the European Union is, in its broadest context, defined as the fulfilment of the so-called Copenhagen Criteria. Apart from these basic criteria, one additional criterion was added in 1995, in Madrid. This refers to the harmonisation of the administrative, governing and judicial structures with EU norms in order to ensure that the EU legislative framework is efficiently implemented.

Bearing in mind the experiences of the fifth enlargement, the European Council adopted in December 2006 its so-called Enlargement Consensus. ${ }^{1}$ Namely, all future enlargements will be subject to a more detailed pre-accession dialogue and a more complex negotiations process. In that way, the process becomes tougher in the very fight for the status of candidate country, and this is based on a country having to be 'ready in an earlier phase' for the obligations stemming from full-fledged membership of the EU.

1 European Council (2006) Presidency conclusions of the Brussels European Council Brussels, 14-15. December. 
The EU will keep its door open for new members, which are candidates or potential candidates, provided that these countries fulfil re-defined accession criteria which are both stricter and more verifiable.

At the same time, by introducing the Copenhagen Criteria as regards the applications of future member states at the level of the Treaty, ${ }^{2}$ the association and accession negotiations have become more complex and more demanding.

\section{Western Balkans region and the enlargement dynamic}

The region of the western Balkans, surrounded by the EU, represents a market of 24 million consumers; a space for new investment and business opportunities, and economic partnerships; a location of financial activities for European banks; opportunities for infrastructure networking; a source of energy resources; and a destination for tourism. The logical and anticipated conclusion of the EU is that the region represents an opportunity regarding the future enlargement of the EU. Bearing in mind that enlargement has been one of the Union's most successful projects over the past few decades, nobody predicted the need to calculate the issue of the EU's absorption capacity for future enlargement and the tangible readiness for integration of the region. The set of Copenhagen criteria had simply been accompanied by the condition of regional stability, stabilisation and an 'own merit' approach.

Most of the countries, despite a similar political and economic legacy, today represent a complex structure of seven small countries, ${ }^{3}$ utterly different and divided, with six official languages and more than $5000 \mathrm{~km}$ of new borders which include a few open border disputes. It is, at least, unique in one important respect, however - possessing European integration as a common strategic priority. Nobody dares to propose an alternative development scenario, in spite of the disappointment with EU integration dynamics.

The regional picture of the western Balkans is traditionally a mosaic of 'troublemakers' and relatively 'boring' countries. Today, regional European integration dynamics is at a very different level, without positive knock-on effects. Competition in the speed of integration did not create synergies in regional stability, nor a real improvement in neighbourly relations to the expected degree.

Croatia has a clear and credible perspective of joining soon, declaring itself rather as a country of south-eastern Europe, the same as some other countries in that context which are already EU members (Romania, Bulgaria, even Slovenia), rather than as a part of the still-problematic western Balkans, which is sometimes referred to as the 'region of unsolved projects'.

Until recently, there was also growing optimism about the future of Macedonia, perceived (including by itself) as a possible model for positive domestic change and moderation, and rewarded by the EU with candidate status in 2005 . Now, there is again rising concern about its future, i.e. concerning its integration dynamics.

2 'The conditions of eligibility agreed upon by the European Council shall be taken into account', Treaty on European Union, Article 49, para. 1.

3 The potential candidate countries are - Albania, Bosnia and Herzegovina, Montenegro, Serbia and Kosovo; the candidate countries are - Croatia, FYRoM and Turkey (as well as Iceland). 
Contrary to even the most pessimistic expectations in 2000, Serbia, estimated by many sides as the country with the biggest administrative capacities and economic potential for rapid progress, has somehow always failed to realise the Union's expectations and is still not a candidate for membership of the EU.

Albania, which achieved the important integration goal of NATO membership in 2009, is, as an Adriatic country, proceeding gradually towards the EU, trying at the same time to support the integration of its eastern neighbours.

Montenegro, may be the smallest of these countries, but it is a country with a growing stability, having a secure Euro-Atlantic perspective and a strong domestic political consensus in favour of EU integration.

Somehow in the last group there are Bosnia and Herzegovina, and Kosovo. Who would have expected a few years ago that there would still be a High Representative in Bosnia and Herzegovina in 2010, concerned about a possible break-up of the country? Who today can estimate when Kosovo will be on a negotiation track, fully responsible for its own European future and supported by all EU member states?

Bearing in mind the regional integration picture presented here, one can conclude that the enlargement process has today transformed itself into a kind of 'enlargementplus' approach. The criteria are higher, the requests stronger and the sensitive transition from being a potential candidate, via the Commission Opinion, to candidate status and the opening of formal negotiations starts to become a real European challenge.

This is partly because of the current integration capacities of the western Balkans, the tiny democracies and the vulnerable and non-competitive economic structures; and partly because of the low level of absorption capacity in the EU, where requests for the deepening of the EU are today much stronger than those for enlargement towards new members. Are there other factors between these two standpoints? Certainly, a third group of reasons for the weak integration dynamic of the western Balkans lays in the lessons learned from the 2007 enlargement. This group of reasons are mostly negative, reflecting a raising of suspicions among EU member states as regards whether potential candidates from the western Balkans really deserve a faster integration track.

In this context, it is obvious that, in the case of the western Balkans, the process of accession is not just about meeting the standards of the common market but also involves complying with criteria for state-building and security. This includes the offering of concrete, viewable results in the fulfilment of political criteria during the early phases of accession. It is a quite new moment in enlargement practice.

The problem with this enlargement-plus standard is the lack of unified indicators applicable to every country in the region. It leads to new EC practices, such as the early introduction of different screening mechanisms even before the Opinion and award of candidacy status, which makes the entire process much more complex. Potential candidate countries face a larger scale of additional questions in the Questionnaire, numerous expert missions in almost all policy areas, including the judicial system, and a much more intensive dialogue under the monitoring of the SAA commitments through different regular committee meetings. Public pressure is much stronger, the internal incountry dialogue is tougher, the perception of rigid requests for future EU membership becomes more present and, accordingly, the expectation of citizens becomes more focused. 
The European Commission has developed a whole mechanism to prevent the more rapid integration of western Balkans countries without the fulfilment of all the criteria. The main pillars of this mechanism are as follows:

- clear confirmation of the fulfilment of all the political criteria is a precondition for the Opinion - the introduction of the 'Opinion with benchmarks' mechanism, having a time-limited framework for control of the achieved indicators before any further steps may be taken

- better transparency and effective state administration, the independence and efficiency of the judicial system, specific results in the fight against corruption and organised crime, the independence of regulatory bodies, full international co-operation in judicial matters - all have strong political implications and need to be deeply monitored even before candidacy status is reached

- it is a preference of the EU to omit a precise date for the opening of accession negotiations even once candidacy status has been achieved

- it is preferable for a candidate country to comply with the entire acquis communautaire prior to accession without counting on any post-accession monitoring mechanisms as a guarantee for the delivery of all the promises and commitments

- it is a preference of the EU to omit a precise entry date from the treaty with candidate countries, leaving open the possibility of postponing accession. In any case, it is crucial to distinguish between the political and technical reasons

- communications, conditionality and consolidation ${ }^{4}$ continue to be the main pillars of the enlargement dialogue, preventing the control of expectations on both sides of the negotiations process.

The EU does, however, need to take two further steps to separate bilateral disputes out of the accession process. First, it should create a new chapter in the negotiations on regional co-operation, such that this would be the only space for the discussion of bilateral issues so that these cannot spill over into other chapters and thus block negotiations. Second, the EU should insert a specific clause into every future accession treaty - starting with Croatia - to prevent new members from wielding a veto because of bilateral disputes.

Today, all the countries of the western Balkans are part of the Stabilisation and Association Process; as such, they are involved in the realisation of European and regional agendas. Their dynamics are provided in Table 1:

4 Communication from the Commission (2005) Enlargement Strategy Paper Brussels, 9 November 2005, $\operatorname{COM}(2005) 561$ pp. 1-3. 
Table 1 - Stabilisation and Association Process in the western Balkans (September, 2010)

\begin{tabular}{|c|c|c|c|c|c|c|}
\hline Phase of the process & Croatia & $\begin{array}{l}\text { Mace- } \\
\text { donia }\end{array}$ & Albania & $\begin{array}{l}\text { Bosnia } \\
\text { and } \\
\text { Herze- } \\
\text { govina }\end{array}$ & Serbia & $\begin{array}{l}\text { Monte- } \\
\text { negro }\end{array}$ \\
\hline $\begin{array}{l}\text { Start of dialogue with EC/ } \\
\text { Progress reports (from } \\
\text { 2002) }\end{array}$ & 2000 & 1998 & 2000 & 1998 & \multicolumn{2}{|c|}{2001} \\
\hline Signing of the SAA & $29 / 10 / 01$ & $9 / 4 / 01$ & $12 / 6 / 06$ & $15 / 6 / 08$ & $28 / 4 / 08$ & $15 / 10 / 07$ \\
\hline $\begin{array}{l}\text { Opening of the market for } \\
\text { EU }\end{array}$ & $\begin{array}{l}6 \text { years } \\
\text { from } 2008\end{array}$ & $\begin{array}{l}10 \text { years } \\
\text { from } 2012\end{array}$ & $\begin{array}{l}10 \text { years } \\
\text { from } 2017\end{array}$ & $\begin{array}{l}5 \text { years } \\
\text { from } 2013\end{array}$ & $\begin{array}{l}6 \text { years } \\
\text { from } 2015\end{array}$ & $\begin{array}{l}5 \text { years } \\
\text { from } 2013\end{array}$ \\
\hline $\begin{array}{l}\text { Application for } \\
\text { membership }\end{array}$ & $21 / 2 / 03$ & $22 / 3 / 04$ & $24 / 4 / 09$ & (2010) & $27 / 12 / 09$ & $15 / 12 / 08$ \\
\hline Questionnaire & $\begin{array}{c}\text { 9/7/03 } \\
/ 9 / 10 / 03\end{array}$ & $\begin{array}{c}1 / 10 / 04 \\
/ 15 / 2 / 05\end{array}$ & $\begin{array}{l}20 / 12 / 09 \\
/ 13 / 4 / 10\end{array}$ & (2010) & (2010) & $\begin{array}{l}22 / 7 / 09 \\
/ 9 / 12 / 09\end{array}$ \\
\hline Avis/Opinion & April 2004 & $\begin{array}{l}\text { Nov. } \\
2005\end{array}$ & $\begin{array}{l}(9 \text { Nov. } \\
2010)\end{array}$ & (2011) & (2011) & $\begin{array}{l}\text { (9 Nov. } \\
2010)\end{array}$ \\
\hline Candidate country & $18 / 06 / 04$ & $9 / 12 / 05$ & $(2010 / 11)$ & (2011) & (2011) & $(2010 / 11)$ \\
\hline Entry into force of SAA & 1 Feb. 2005 & $\begin{array}{l}1 \text { April } \\
2004\end{array}$ & $\begin{array}{l}1 \text { April } \\
2009\end{array}$ & (2011) & (2011) & $\begin{array}{l}1 \text { May } \\
2010\end{array}$ \\
\hline $\begin{array}{l}\text { Initiation of negotiations } \\
\text { on EU membership }\end{array}$ & $\begin{array}{l}\text { 3/11/05 } \\
\text { (to be } \\
\text { concluded } \\
\text { by 2011) }\end{array}$ & (2011) & $(2011 / 12)$ & (2012) & $(2011 / 12)$ & $(2011 / 12)$ \\
\hline
\end{tabular}

Source: Official data from the governments of the region compiled here by the authors.

* Data in brackets represent the assessment of the authors, September 2010.

Within the region, Croatia and Macedonia obtained the Opinion and candidacy status respectively in 2004 and 2005. Montenegro and Albania expect an Opinion in November 2010, while Montenegro expects candidacy status soon after the Opinion; consequently, the end of 2011 /start of 2012 could be a period for the initiation of negotiations. Montenegro believes that granting it candidate status and clearly spelling out the beginning of accession negotiations by the end of 2011 would be both justified and timely.

Slowly but surely, Montenegro is starting to play a leading role among the potential candidate countries for membership, being the first country to enter the demanding enlargement-plus process. Thus, it is paving the way for other countries in the region towards faster integration, and is also raising its voice against any form of 'Balkan waiting room' for membership of the EU. 
Other countries in the region have potential candidate country status. They expect to become candidate countries during 2011, which leads us to the general expectations that, in 2012, the EU can consider opening accession negotiations with the majority of, or all, western Balkans countries.

The regional picture: lobbying for a faster integration track for the region as a whole

Some authors have recommended ${ }^{5}$ that the EU send a Questionnaire immediately to each of the three countries that has not yet received one: Bosnia, Serbia and Kosovo. If Serbia were to return its Questionnaire before the end of 2010, the Commission could prepare its Avis in 2011 in parallel with the screening process (joint screening exercises in 2011; with all six countries thus beginning the screening process together, rather than separately, as the central European applicants did in 1998, prior to accession negotiations). A collective screening exercise for the Balkan countries would take around six months. Finally, it is recommended that it be assessed whether a group of countries could begin talks together in 2012, even though the best-case accession date already lies beyond 2020 .

Under this scenario, the regional image and dynamics of European events could look like this: if we presume that Croatia concludes negotiations on accession in 2011 and becomes a member state in 2012, while other countries in the region will become candidate countries for membership, substantially ready to open negotiations, it is possible to imagine several scenarios concerning the year of the possible conclusion of negotiations for each individual country. That year is perceived as the year of 'internal readiness' for membership, from the point of view of the acceding country.

Proceeding from the assumption that the second group of countries covered by the fifth enlargement had initiated accession negotiations in February 2000 and had concluded them by the end of 2002, it could be expected that negotiations 'must' last at least three years. Finally, the analysis should include Kosovo as well. The possible scenarios are demonstrated in Table 2.

Table 2 - 'Internal readiness' for EU membership and scenarios for the conclusion of negotiations

\begin{tabular}{|l|c|c|c|c|c|c|}
\hline & $\begin{array}{c}\text { Mace- } \\
\text { donia }\end{array}$ & $\begin{array}{c}\text { Monte- } \\
\text { negro }\end{array}$ & Albania & Serbia & Kosovo & B\&H \\
\hline $\begin{array}{l}\text { Start of accession } \\
\text { negotiations }\end{array}$ & 2012 & 2012 & 2012 & 2012 & - & 2012 \\
\hline $\begin{array}{l}\text { 'Internal readiness' - } \\
\text { regional approach }\end{array}$ & 2015 & 2015 & 2015 & 2015 & $(2018)$ & 2018 \\
\hline $\begin{array}{l}\text { Alternatives of 'two } \\
\text { regattas' scenario in the } \\
\text { period 2015-2018 }\end{array}$ & \multicolumn{7}{|c|}{1} & \multicolumn{2}{|c|}{2} \\
\cline { 2 - 7 } & \multicolumn{3}{|c|}{1} & \multicolumn{5}{|c|}{2} \\
\hline
\end{tabular}

5 Heather Grabbe, Gerald Knaus and Daniel Korski (2010) Beyond wait-and-see: the way forward for EU Balkan policy European Council on Foreign Relations, ECFR/21, policy brief, May. 


\begin{tabular}{|l|c|c|c|c|c|c|}
\hline & $\begin{array}{c}\text { Mace- } \\
\text { donia }\end{array}$ & $\begin{array}{c}\text { Monte- } \\
\text { negro }\end{array}$ & Albania & Serbia & Kosovo & B\&H \\
\hline $\begin{array}{l}\text { Realistic scenario } \\
\text { - regional approach }\end{array}$ & 2018 & 2018 & 2018 & 2018 & $(2018)$ & 2018 \\
\hline Pessimistic scenario & $2020-$ & $2020-$ & $2020-$ & $2020-$ & $2020-$ & $2020-$ \\
\hline
\end{tabular}

Source: Calculation of the authors, October 2010.

\section{The 'regatta': lobbying for a faster integration track based on the 'own-merit' approach}

There is no doubt that the approach mentioned in the previous section is being prepared with the good intentions of supporting a more rapid integration process - or, at least, the joint opening of negotiations. The problematic aspect to it is, however, that it annuls the 'own merit' path and re-introduces a regional approach, i.e. that the integration dynamic of the region depends on the dynamic of the integration of the so-called 'troublemakers', under which the 'boring countries' should only pray for the 'better health' of their neighbours.

Montenegro, as the smallest country in the region, is very open and very co-operative, and a country which, at the same time, fully respects regional policy, trying to develop good neighbourly relations with all. For Montenegro, there are no certain shortcuts and it fights strongly for each small step on the EU path, always under the risk of being classified in the western Balkans waiting room.

In other words, if a country fulfils the conditions for candidacy status, or the opening of accession negotiations, it would be fair to allow that country to go further and reward its efforts. It is said that 'enlargement is not for tomorrow', but the process itself is highly important and we think that it is an EU commitment to have a 'fair and rigorous' accession process - i.e. to allow every country to move forward according to its own individual pace. Therefore, countries from the region, such as Montenegro, should remind the Commission of the need to operate the criteria in the same extent and manner for all - 'each country on its own merits'.

For instance, 'punishing' Montenegro to wait longer for the opening of accession negotiations than is objectively necessary could not be regarded as fair. If the EU wants to create a competitive and fair environment for integration in the region, it should reconsider the application of an equal approach for all. How can a country be motivated to work harder if it knows that the dynamics of integration depend on the dynamics of its neighbours? In other words, countries such as Montenegro need to draw attention to positive cases and the creation of positive spill-over effects in the region.

In this still very early phase of integration, it is very important to keep the same rules and procedures as laid down in the Thessaloniki Agenda. What is required is a clear mechanism which could be created for each particular country on the grounds of an approach rooted in the basis of merit or achieved results. This will facilitate the transparency of the accession process and provide additional motivation for the authorities to continue with democratic and economic reforms in the countries of the region. 


\section{The importance of lobbying}

Lobbying is a modern and legitimate form of the representation and promotion of wide-spectrum interests in the contemporary political environment. Every country which has a strategic goal of joining the EU needs to prepare itself for this process in order to enable its active, professional and factual co-operation with EU decision-making processes. The administrations of recent EU member states, countries negotiating membership and those which have yet to open such a process are faced with significant problems in communicating with EU institutions in Brussels. Therefore, it is necessary for potential candidate countries for EU membership promptly to understand the protocols and the rules of functioning of the complex EU system, as it means co-operating with more than 1000 committees existing in Brussels, as well as with a significant number of supra-national and inter-governmental bodies encompassed by the creation of official EU policy.

Concerning the countries of the region, Croatia undoubtedly has the best established lobbying office currently in Brussels, along with an office in Zagreb. Here, political, economic and other analyses are carried out and it is also where an appearance strategy is created for those using the services of the lobbying office vis-à-vis the European institutions. Croatian websites are extremely well-organised and contain numerous data on development and the harmonisation of regulation, both of which are important for accession negotiations. By surfing Croatian websites, one can form an impression of organisation and seriousness in all areas of local society activities. Priorities mainly relate to the accession of Croatia to the EU and the possibility of finding development funds. ${ }^{6}$

When it comes to lobbying and networking, Montenegro is still in the initial phase. The Ministry of Foreign Affairs is developing a network of Montenegrin embassies throughout EU countries, including a Permanent Mission of Montenegro to the EU in Brussels. The Ministry of Finance has prepared a draft law on lobbying activities which will regulate this field in accordance with international standards, including the establishment of a register of lobbyists.

In the meantime, lobbying has been left to state institutions communicating with European institutions, as well as to the large number of civil society organisations that are mainly specialised in human rights and the rule of law. A unique platform for lobbying in the national interest does not exist, so numerous CSOs are involved in the preparation of critical reports that do not support the affirmation of the European perspective of the country. A large number of NGOs, as the European Commission itself stated in the 2009 Progress Report, act as strong political actors with the intention of being transformed into a new political offer on the country's public scene. A consensus on the protection of national interests has not yet been established, so the 'trade in information' sometimes develops into the protection of the interests of certain interest groups colliding with the concept of an independent Montenegro and its European affiliation.

6 Stančetić Veran Linija razgraničenja: plansko i organizovano uticanje na proces donošenja odluka, lobiranje u EU:

http://www.danas.rs/dodaci/vikend/plave_strane/lobiranje_u_EU.45.html?news_id=184656/. 
This is a complex process which confirms that Montenegro renewed its statehood in May 2006 but that it still needs time for stronger communication with all interest groups in accordance with the main interests of the state. Stronger representation and lobbying by Euro-groups has not yet been developed, except in the field of the protection of the environment and the fight against corruption. Profit-oriented organisations (legal advisors, PR companies, consultants) are not so widespread in Montenegro. In addition, the English language web presentations of Montenegrin state institutions are not sufficiently developed or available. ${ }^{7}$

Bearing in mind all these issues, recommendations for lobbying and networking towards the EU are as follows:

- an institutional set-up for lobbying should be established

- a register of professional lobbyists needs to be established and available on the web

- a code of conduct, i.e. minimal standards common to all lobbyists, needs to be set up with mechanisms for external monitoring and auditing, as well as sanctions in case of violations

- recalling that lobbying is the political management of information, the lobbyist needs to understand the relevant machinery of decision-making and then to seek to influence the process

- the activities of lobbyists and NGOs needs to be made more transparent in terms of the interests represented and the sources of their funding.

\section{Concluding remarks}

'Internal readiness' is a term created by western Balkan countries themselves, and it implies an incentive mechanism for local stakeholders to work faster on the European agenda and planned reforms. It means a date prior to the closure of accession negotiations when a country estimates itself to be ready for its post-accession obligations, which is directly connected with issues depending entirely on the country itself and its domestic policy (excluding external factors such as the neighbours and the EU in terms of its own capacity for integration). Internal readiness is sometimes quite confusing for the EU, but is very clear as regards the domestic public scene.

A realistic scenario for the regional integration dynamic (2018) implies the realisation of the integration process via several 'regattas' for the countries of the region. So far, the composition of the regattas is not certain but, according to one approach, the first regatta could consist of Macedonia, Montenegro, Albania and Serbia, while the second could consist of Bosnia and Herzegovina and Kosovo. According to another approach, the composition of the regattas would be different, with the first consisting of Macedonia and Montenegro while all the other countries in the region would be covered by the second.

The pessimistic scenario represents a less desirable option according to which 2020 would be the possible year of full membership for the western Balkan countries. Bearing

7 Djurović Gordana (2010) Crna Gora u XXI stoljeću - u eri kompetitivnosti, podprojekat: Integracije u evropske i evroatlanske strukture Crnogorska akademija nauka i umjetnosti, Podgorica, pp. 214-222. 
in mind that the political elites of all the countries of the region have defined European integration as their strategic priority, as well as that the EU has confirmed, on several occasions, that its doors are open to the western Balkans, we are of the opinion that this option is less realistic and, at the same time, very disappointing for the region.

Moreover, apart from stricter accession criteria and the reflection of all lessons learned from the fifth enlargement, the regional dynamics of accession will depend mostly on meeting specific criteria defined for the countries of this region. This primarily involves a regional aspect to stability and the promotion of good neighbourly co-operation, including the resolution and conclusion of all open issues between the countries of the region (related to borders, names and other political issues). Finally, all individual, specific political criteria referring to each individual country in the region needs also to be met.

To conclude, there is the singular opinion that we should lobby for a faster European integration track for the western Balkan region. The number of topics that connect the countries of the region is growing as time goes by and the region itself comes closer to the EU. Lobbying for each country separately means lobbying for the region as a whole. Gradually, however, the problems that slow down the process will be resolved and positive competition will prevail. Western Balkan countries need to believe in a joint European future in order to create one.

\section{References}

Communication from the Commission (2005) Enlargement Strategy Paper Brussels, 9 November 2005, COM(2005)561.

Djurović Gordana (2010) Crna Gora u XXI stoljeću - u eri kompetitivnosti, podprojekat: Integracije u evropske i evroatlanske strukture Crnogorska akademija nauka i umjetnosti, Podgorica.

European Council (2006) Presidency Conclusions of the Brussels European Council Brussels, 14-15 December.

Heather Grabbe, Gerald Knaus and Daniel Korski (2010) Beyond wait-and-see: the way forward for EU Balkan policy European Council on Foreign Relations, ECFR/ 21, policy brief, May.

Stančetić Veran Linija razgraničenja: plansko i organizovano uticanje na proces donošenja odluka, lobiranje u EU,

http://www.danas.rs/dodaci/vikend/plave_strane/lobiranje_u_EU.45.html?

news_id=184656/

Treaty on European Union (2008) 2008/C 115/01 Official Journal of the EU C 115, Volume 51, 9 May. 